cal difference between groups concerning the parameters analyzed except that the biopolymer has been slowly absorbed $(\mathrm{p}<0.001)$.

Conclusion: The sugar cane biopolymer membrane can be used as dural substitute in rats and it evolves to be absorbed by the hostess.

Key words: dura-mater, sugar cane biopolymer, expanded polytetrafluoroethylene.

*Membrana de biopolímero de cana de açúcar como substituto de dura-máter em ratos /wistar (Resumo). Tese de Doutorado, Universidade Federal de Pernambuco (Área: Cirurgia clínica e experimental ). Orientador: José Lamartine de Andrade Aguiar .

**Address: Rua Astronauta Neil Armstrong 65 / 401 - 52060-170 Recife PE - Brasil (E-mail: fredericotavaresdelima@ibest.com.br).

\title{
CLIMACTERIC AND COGNITION: THE SCORES OF A SAMPLE OF CLIMACTERIC WOMEN IN MINI-MENTAL STATE EXAMINATION AND WORD-LIST MEMORY TEST (ABSTRACT)*. DISSERTATION. RIO DE JANEIRO, 2007.
}

\section{RITA DE CÁSSIA LEITE FERNANDES**}

Introduction: In Brazil, research on cognition and climacteric is scanty, despite the great prevalence of memory complaints in this phase of the female life. The objective of this research was to describe the scores of climacteric women in neuropsychological tests and to verify possible associations with sociodemographic, clinical, gynecological and depressive characteristics.

Method: 156 women, ranging from 40 to 65 years old, were evaluated with two neurocognitive tests and a depressive scale: Mini-Mental State Examination (MMSE), Word-List Memory Test (WLMT) and CESD (Center for Epidemiological Studies Depressive Scale).

Results: The average scores obtained in MMSE ( $M=25.86$; $S D=2.67$ ) were different to the ones found in other stratum within the Brazilian population only to illiterate climacteric women, who scored higher ( $M=21.72 ; S D=3.77)$. There was a trend for underscoring only the questions for attention and copy in the MMSE items. The average score in WLMT was similar to the ones obtained by other authors ( $M=18.83$; $S D=3.82)$. There were no significant relationships between the average scores on the tests and climacteric period, demographic characteristics, intensity of depressive symptoms and clinical or gynecological conditions, except for lower scores obtained by hypertensive women in WLMT. The Z score of nine women (5.7\%) were found to be below 1.5 SD in WLMT.

Conclusions: We concluded that these average scores, in a specific population cut point, did not exhibit differences chargeable to their peculiar characteristics. The lowering of attention may justify some of the frequent memory complaints of climacteric women. The low scores obtained by some women in the WLMT requires further investigations.

Key words: climateric, menopause, cognition, depression, neuropsychological tests.

*Climatério e cognição: desempenho de um grupo de mulheres climatéricas no mini-exame do estado mental e no teste de memória da lista de palavras (Resi,p). Dissetação de Mestrado, Instituto Fernandes Figueira / Fundação Oswaldo Cruz (FIOCRUZ) - Rio de Janeiro (Área: Saúde Coletiva). Orientadoras: Lizanka Paola de Figueirrfp; Silvia Eliane Vasconcelos Zahar.

**Address: Rua Marquês de Abrantes 171 / 502 - 22230-060 Rio de Janeiro RJ - Brasil (E-mail: ritaf@globo.com).

\section{FREQUENCY OF MAJOR DEPRESSIVE DISORDER IN HTLV-I INFECTED PATIENTS (ABSTRACT)*. DISSERTATION. RIO DE JANEIRO, 2007.}

\section{ALESSANDRO ROCHA MILAN DE SOUZA**}

Introduction: Symptoms of depression are fairly common among hospitalized patients and they are part of the diagnostic criteria for major depressive episode, as defined by DSMIV. These symptoms consist of changes in appetite, sleep disturbances, agitation or psychomotor retardation, fatigue or loss of energy, feelings of uselessness or excessive guilt, a decrease in thinking capacity or in concentration and recurring thoughts about death. Major depression is characterized by changes in mood and in interest levels, as well as other symptoms, that persist in a period of at least two weeks. It occurs at a rate of 2 to $6.6 \%$ in the population at large and 5 to $10 \%$ in hospitalized patients. Symptoms of depression are common during or following viral infections. Nevertheless, showing an association between an episode of major depression and viral infections remains a controversial topic.

Objective: To evaluate the prevalence of the major depression episode and of symptoms of depression in patients infected with the HTLV-I virus. 